\title{
Kepadatan Dan Persebaran Kepiting (Brachyura) Di Ekosistem Hutan Mangrove Segara Anakan Cilacap
}

\author{
Sri Redjeki*, Mas'ad Arif, Retno Hartati, dan Laras Kinanti Pinandita \\ Departemen IImu Kelautan, Fakultas Perikanan dan IImu Kelautan, Universitas Diponegoro \\ JI. Prof. Soedarto, SH. Kampus UNDIP Tembalang, Semarang 50275 \\ Email : sriredjekikelautan@gmail.com
}

\begin{abstract}
Segara Anakan area is a lagoon surrounded by mangrove forests and muddy land. Mangrove forests have an ecological function such as spawning ground, nursery ground, and feeding ground for various biota. The destruction of mangrove forests caused by human activities is quite alarming and affects the survival of living biota in it, one of them is crabs. Changes in the structure and composition of the crabs in mangrove ecosystems caused by habitat changes can be used as an indicator for water quality by biological index approach through population monitoring, community composition, or even the ecosystem function. So that, by the study of abundance and distribution of crabs on mangrove vegetation, the results can be used as monitoring of environmental conditions of mangrove ecosystems in Segara Anakan Area. This research was conducted to determine about the composition, abundance, diversity index, uniformity index, dominance index, and pattern of distribution of crabs on mangrove ecosystems in Segara Anakan, Cilacap. The sampling was conducted in July, 2016 in 3 locations namely Panikel, Bondan, and Kalibuntu. To determine the sampling location using random method of stratification. Crab sampling using $5 \mathrm{~m} \times 5 \mathrm{~m}$ transect method in 3 stations with 3 repetitions at each station. The results of this research found 12 species consisting of 3 families of crabs. Ocypodidae Family is the most commonly crabs found in 3 location. The highest abundance of crab is in Kalibuntu $\left(1,56 \mathrm{ind} / \mathrm{m}^{2}\right)$ an the lowest abundance is in Panikel $\left(1,27 \mathrm{ind} / \mathrm{m}^{2}\right)$. There are two pattern of distribution of crabs in this research, namely random and clumped. The diversity index values are in the medium category, whereas the uniformity index value is in the high category. In this research there is no dominance in all research location.
\end{abstract}

Keywords : Crab, Mangrove, Abundance, Distribution, Structure of Community

\begin{abstract}
Abstrak
Kawasan Segara Anakan merupakan laguna yang dikelilingi oleh hutan-rawa mangrove yang luas dan daratan berlumpur. Hutan mangrove memiliki fungsi ekologis antara lain sebagai tempat pemijahan, pembesaran, dan mencari makan bagi berbagai biota didalamnya. Kerusakan hutan mangrove yang terjadi karena adanya aktivitas manusia cukup mengkhawatirkan dan berpengaruh terhadap kelangsungan hidup biota yang hidup didalamnya, salah satunya adalah kepiting. Perubahan struktur dan komposisi kepiting pada ekosistem mangrove yang diakibatkan oleh adanya perubahan habitat dapat dijadikan indikator kualitas perairan dengan pendekatan indeks biologi melalui monitoring jumlah populasi, komposisi komunitas maupun fungsi ekosistemnya. Sehingga dengan dilakukannya kajian tentang Kepadatan dan Persebaran kepiting pada vegetasi mangrove hasilnya dapat digunakan sebagai monitoring kondisi lingkungan ekosistem mangrove di Kawasan Segara Anakan. Penelitian ini dilakukan untuk mengetahui komposisi, kepadatan, indeks keanekaragaman, keseragaman, dominansi, dan pola sebaran kepiting pada ekosistem mangrove di Segara Anakan Cilacap. Pengambilan sampel dilaksanakan pada bulan Juli 2016 di 3 lokasi yakni Desa Panikel, Bondan, dan Kalibuntu. Penentuan lokasi sampling dengan metode acak berstratifikasi Pengambilan sampel kepiting menggunakan metode transek $5 \mathrm{~m}$
\end{abstract}


$\times 5 m$ dengan jumlah stasiun sebanyak 3 dan 3 kali pengulangan pada setiap stasiunnya. Hasil penelitian ditemukan 12 jenis spesies yang terdiri dari 3 famili kepiting. Famili Ocypodidae paling banyak ditemukan pada 3 lokasi penelitian. Kepadatan kepiting tertinggi terdapat pada Lokasi Kalibuntu (1,56 ind./m2) dan terendah di Lokasi Panikel (1,27 ind/ m2). Terdapat dua pola sebaran kepiting di lokasi penelitian, yaitu acak dan mengelompok. Nilai Indeks Keanekaragaman masuk dalam kategori sedang, sedangkan nilai indeks keseragaman dalam kategori tinggi. Dalam penelitian ini tidak terdapat dominansi pada seluruh stasiun penelitian.

Kata Kunci : Kepiting, Hutan Mangrove, Kepadatan, Persebaran, Struktur Komunitas

\section{PENDAHULUAN}

Mangrove merupakan ekosistem yang didalamnya terjadi interaksi yang kuat antara komponen daratan dan laut. Interaksi ini menjadikan ekosistem mangrove mempunyai keanekaragam yang tinggi baik berupa flora maupun fauna (Akbar, 2017). Secara ekologis, hutan mangrove berfungsi sebagai tempat pemijahan (spawning ground), tempat asuhan (nursery ground), mencari makan (feeding ground) bagi berbagai biota laut (Prasetiyo et al., 2006).

Keberadaan hutan mangrove Segara Anakan sekarang ini cukup mengkhawatirkan karena adanya aktivitas manusia seperti penebangan liar, konversi lahan untuk kegiatan perikanan, industri, pemukiman, dan tempat wisata, serta laju sedimentasi yang tinggi (Dewi, 2016). Hal tersebut menyebabkan tekanan semakin tinggi terhadap Kawasan Segara Anakan dan memicu turunnya produktivitas perairan dan secara tidak langsung mempengaruhi kondisi biotabiota yang hidup di kawasan hutan mangrove termasuk kepiting

Kepiting memiliki peran penting secara ekologis sebagai pengkonversi nutrien, mempertinggi mineralisasi, dan meningkatkan distribusi oksigen di dalam tanah. Prianto (2007) menyatakan bahwa kepiting di ekosistem mangrove berkedudukan sebagai spesies kunci yang melibatkan biota lain dalam aktivitas makan serta sebagai pengurai serasah mangrove untuk sebagian dimakan dan dicacah.

Kajian tentang pendekatan kepadatan dan persebaran kepiting sendiri dapat dijadikan sebagai monitoring kualitas suatu perairan (Rosenberg dan Resh, 1993), sehingga dalam hal ini diduga dengan dilakukannya kajian tentang keberadaan dan pendekatan kepadatan dan persebaran dapat digunakan sebagai monitoring kondisi lingkungan ekosistem mangrove di Kawasan Segara Anakan, Cilacap.

Penelitian ini bertujuan untuk mengetahui komposisi, kepadatan, keanekaragaman, keseragaman, dominansi, dan Pola Sebaran kepiting (Brachyura) pada ekosistem hutan mangrove Segara Anakan, Cilacap.

\section{MATERI DAN METODE}

Penelitian dilakukan pada bulan Juli 2016 di 3 lokasi yakni Desa Panikel, Bondan, dan Kalibuntu. Metode penelitian dengan metode deskriptif. Penentuan lokasi sampling dengan metode sampling acak berstratifikasi yaitu dengan membagi lokasi sampling menjadi beberapa lapisan atau strata berdasarkan karakteristik tertentu. Karakteristik yang diperhatikan antara lain : penyebaran mangrove jenis dan kerapatannya, dampak kegiatan manusia, dan karakteristik lainnya yang terdapat pada stasiun-stasiun tersebut. Pengambilan data dilakukan dengan tiga kali pengulangan pada setiap lokasinya.

\footnotetext{
Pengambilan sampel kepiting dalam vegetasi mangrove dengan menggunakan tali transek kuadrat $(5 \times 5$ $\mathrm{m}^{2}$ ) dengan pengulangan tiga kali pada setiap lokasi penelitian.
}

Kepiting yang ada dijumpai di permukaan substrat diambil dengan tangan (hand picking) dibersihkan dan 

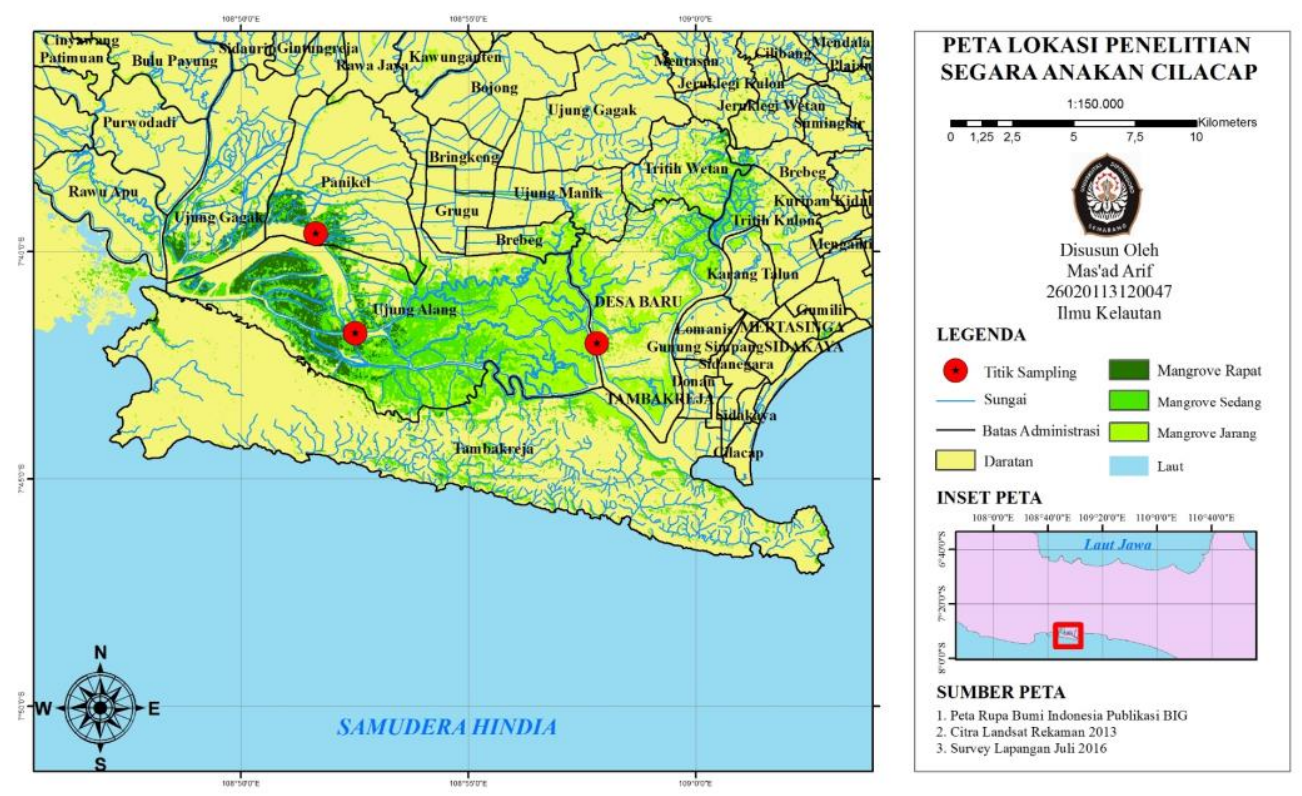

Gambar 1. Peta Lokasi Penelitian Segara Anakan Cilacap Jawa Tengah

dimasukkan kedalam kantong plastik sampel, serta diberi larutan alkohol $70 \%$ sebagai pengawet (Sasekumar, 1984). Pengambilan sampel dilakukan pada saat air surut, karena kepiting akan bergerak aktif pada kondisi tersebut, sehingga memudahkan dalam pengambilannya.

Identifikasi sampel kepiting menggunakan referensi buku indentifikasi Crabs of Japan and The Adjacent Seas (Sakai, 1957), FAO (1998), dan Hsi - Te Shih (2016).

\section{Analisis Data}

Analisa kepadatan kepiting dihitung dengan rumus Krebs (1978). Indeks Keanekargaman $\left(\mathrm{H}^{\prime}\right)$ jenis dihitung menurut Shannon-Wiener dalam Odum (1993). Menghitung Indeks Keseragaman (E) jenis menggunakan rumus Evennex Indeks dari Shannon Indeks of Diversity (Krebs, 1989). Indeks Dominansi dihitung dengan menggunakan rumus Indeks of Dominance dari Simpson (Odum, 1993). Kesamaan komunitas antar stasiun dihitung dengan indeks kesamaan komunitas Bray-Curtis berdasarkan rumus Odum (1993). Pola sebaran jenis kepiting dihitung menggunakan Indeks dispersi Morisita menurut Krebs (1989).

\section{HASIL DAN PEMBAHASAN}

Komposisi kepiting yang ditemukan pada ekosistem mangrove lokasi penelitian didapatkan 12 spesies yang termasuk ke dalam Famili Ocypodidae, antara lain : Uca coarctata, U. crassipes, U. dussumieri, U. tetragonon, dan U. vocans. Famili Grapsidae, meliputi : Episesarma lafondi, E. versicolor, Perisesarma bidens, Metaplax elegans, Metopograpsus latifrons, dan M. mssor. Famili Portunidae hanya ditemukan satu spesies yaitu Scylla serrata.

Ketiga lokasi penelitian ini, jenis Uca sp., Metopograpsus sp., dan Episesarma sp. merupakan jenis kepiting yang paling banyak ditemukan. Kepiting ini ditemukan memanjat di batang akar penyangga, pohon yang pendek, dan struktur kayu lainnya. Hasil ini sesuai dengan pernyataan Pratiwi dan Widyastuti (2013) yang menyatakan bahwa krustasea suku Grapsidae, Sesarmidae dan Ocypopidae merupakan jenis kepiting yang biasanya banyak ditemukan di daerah mangrove.

Famili Ocypodidae memiliki komposisi kepiting terbesar pada penelitian ini, karena dijumpai pada ketiga lokasi penelitian. Ada 4 spesies kepiting dari Famili Ocypodidae yang ditemukan hidup pada semua lokasi penelitian, yaitu 
Uca coarctata, U. crassipes, U. dussumieri, dan U. tetragonon. Komposisi Uca spp. (Ocypodidae) terbesar juga didapatkan pada peneltian Pratiwi dan Rahmat (2015), hal ini diduga lokasi ditemukannya kepiting yang sama yakni di daratan lumpur pinggiran hutan mangrove, lantai hutan, tambak dan daerah bekas tebangan mangrove, sehingga sangat sesuai dengan cara hidup dari kepiting Uca spp.

Famili Grapsidae jenis makanannya adalah serasah dari daun bakau (Pratiwi dan Rahmat, 2015). Jenis kepiting lain yang banyak ditemukan adalah kepiting Metopograpsus spp. Famili Grapsidae, jenis ini merupakan hewan herbivora yang memakan serasah daun mangrove. Kepiting ini juga memiliki kebiasaan menggali lubang untuk melindungi dirinya disaat sedang pasang dan melakukan adaptasi fisio-morfologi (Kusumadewi et al., 2013).

Spesies kepiting dari Famili Portunidae yakni Scylla serrata hanya ditemukan di lokasi Kalibuntu. Menurut Pratiwi dan Widyastuti (2013), hal tersebut terjadi karena adanya pemilihan habitat yang mengakibatkan jenis tertentu dapat ditemukan di satu lokasi sedangkan jenis tersebut tidak dijumpai di lokasi lain. Letak lokasi Kalibuntu berdekatan dengan tepi aliran sungai, tentu hal ini dapat menunjang kehidupannya mengingat Famili Portunidae ini merupakan salah satu jenis kepiting yang biasanya terdapat di daerah dekat pantai, aliran sungai, dan hidup dalam lubang-lubang atau terdapat pada pantai-pantai yang ditumbuhi mangrove (Romimohtarto, 2001).

\section{Kepadatan Kepiting}

Secara umum dari ketiga lokasi penelitian memiliki kepadatan kepiting yang berbeda, Lokasi Kalibuntu memiliki kepadatan kepiting tertinggi dibandingkan ketiga lokasi lainnya yakni sebesar $\quad 1.56$ ind $/ \mathrm{m}^{2}$, sedangkan kepadatan kepiting terendah terdapat pada Lokasi Panikel (1.27 ind $/ \mathrm{m}^{2}$ ). Lokasi Kalibuntu memiliki kepadatan kepiting tertinggi diduga lokasi ini memiliki kondisi lingkungan yang mendukung bagi kehidupan kepiting dengan kandungan bahan organik cukup tinggi yakni 22,42. Kandungan bahan organik tinggi ini karena lokasi Kalibuntu memiliki kerapatan mangrove yang tergolong tinggi ( > 1500 ind/ha). Tingginya kerapatan mangrove menjadikan guguran daun mangrove yang jatuh ke permukaan substrat lebih banyak dan sangat berpengaruh pada kesuburan dan jumlah bahan organik yang terkandung di dalamnya.

Bahan organik sendiri berfungsi untuk menyediakan nutrisi bagi kepiting yang hidup di dalamnya. Lebih lanjut menurut Widyastuti (2016) menjelaskan kepiting berperan dalam memindahkan sejumlah besar sedimen dan merubah karakteristik sedimen, merubah komposisi mikroflora sedimen, mempengaruhi penambahan air dan kandungan bahan organik dalam sedimen serta berperan alam siklus nutrien dan aliran energi.

Kepiting memiliki faktor lingkungan pembatas (batas lethal) dalam mendukung kehidupannya, antara lain suhu, salinitas, pH, tipe substrat dan bahan organik yang terkandung di dalam substrat. Apabila nilai-nilai unsur yang dibutuhkan jumlahnya dibawah atau diatas ambang batas, maka tidak akan ditemukan jenis itu diperairan tersebut (Pratiwi, 2007).

Kepadatan kepiting antara lokasi Bondan dan Kalibuntu relatif sama 1,43 dan 1,56 ind $/ \mathrm{m}^{2}$ ). Hal ini menyebabkan banyak spesies kepiting yang ditemukan sama pada kedua lokasi tersebut. Lokasi Panikel memiliki nilai kepadatan kepiting terendah dibanding lokasi lainnya, karena saat pengambilan sampel kepiting keadaan lokasi penelitian muka air masih pasang, hal ini menyebabkan kepiting belum keluar dari lubang substrat, sehingga secara tidak langsung mempengaruhi jumlah kepiting yang didapat pada lokasi ini.

\section{Keanekaragaman, Keseragaman dan Dominansi Kepiting}

Nilai Indeks Keanekaragaman pada ketiga lokasi penelitian termasuk dalam 
kategori sedang, nilai Indeks Keseragamannya sedang pada lokasi Panikel, sedangkan lokasi Bondan dan kalibuntu termasuk dalam kategori tinggi. Tidak ditemukan dominansi spesies dalam penelitian ini (Tabel 2.).

Nilai indeks keanekaragaman kepiting di lokasi Bondan relatif lebih tinggi $(2,23)$ dibanding dengan lokasi lainnya. Tingginya nilai indeks keanekaragaman kepiting di lokasi Bondan diduga karena kerapatan mangrove di lokasi ini lebih tinggi daripada lokasi Panikel dan Kalibuntu. Hal ini diperkuat oleh Dewi (2016), menyatakan kerapatan hutan mangrove yang tinggi dalam suatu kawasan menyebabkan serasah atau luruhan daun vegetasi mangrove yang dihasilkan sebagai sumber nutrisi organisme di sekitarnya cukup tinggi pula. Kerapatan hutan mangrove yang tinggi akan memberikan perakaran yang kuat dan padat di sekitar kawasan mangrove, sehingga larva-larva kepiting setelah menetas akan dapat menempel pada akar-akar mangrove untuk berlindung. Suryono (2006) menambahkan, yang mempengaruhi nilai keanakaragaman kepiting yang tergolong sedang pada tiap lokasi adalah beberapa jenis kepiting yang mempunyai kecenderungan menetap pada pohon tertentu dan tidak mampu beradaptasi dengan baik terhadap perubahan lingkungan.

Tabel 1. Rata-rata Kepadatan Total (Ind / m²) Kepiting di Lokasi Penelitian

\begin{tabular}{|c|c|c|c|c|}
\hline \multirow{2}{*}{ No } & \multirow{2}{*}{ Spesies } & \multicolumn{3}{|c|}{ Lokasi } \\
\hline & & Panikel & Bondan & Kalibuntu \\
\hline & Ocypodidae & & & \\
\hline 1 & Uca coarctata & 0,35 & 0,27 & 0,25 \\
\hline 2 & Uca crassipes & 0,13 & 0,12 & 0,35 \\
\hline 3 & Uca dussumieri & 0,33 & 0,23 & 0,27 \\
\hline 4 & Uca tetragonon & 0,40 & 0,11 & 0,13 \\
\hline \multirow[t]{2}{*}{5} & Uca vocans & 0,03 & 0,03 & - \\
\hline & Grapsidae & & & \\
\hline 6 & Episesarma lafondi & - & 0,17 & 0,11 \\
\hline 7 & Episesarma versicolor & - & 0,07 & 0,20 \\
\hline 8 & Perisesarma bidens & - & 0,21 & - \\
\hline 9 & Metaplax elegans & 0,03 & 0,05 & - \\
\hline 10 & Metopograpsus latifrons & - & 0,07 & 0,07 \\
\hline \multirow[t]{2}{*}{11} & Metopograpsus messor & - & 0,11 & 0,16 \\
\hline & Portunidae & & & \\
\hline 12 & Scylla serrata & - & - & 0,03 \\
\hline \multicolumn{2}{|c|}{ Jumlah } & 1,27 & 1,43 & 1,56 \\
\hline
\end{tabular}

Tabel 2. Nilai Keanekaragaman, Keseragaman dan Dominansi Kepiting pada Lokasi Penelitian

\begin{tabular}{lllllll}
\hline Lokasi & \multicolumn{2}{c}{ Keanekaragaman } & \multicolumn{2}{c}{ Keseragaman } & \multicolumn{2}{c}{ Dominansi } \\
\cline { 2 - 7 } & $\mathrm{H}^{\prime}$ & Kategori & $\mathrm{E}$ & Kategori & $\mathrm{D}$ & Kategori \\
\hline Panikel & 1,47 & Sedang & 0,57 & Sedang & 0,28 & TAD \\
Bondan & 2,23 & Sedang & 0,64 & Tinggi & 0,12 & TAD \\
Kalibuntu & 2,02 & Sedang & 0,61 & Tinggi & 0,15 & TAD \\
\hline
\end{tabular}

Ket : : Wilhm (1975), "*: Odum (1993), ***: Simpson (1949) 
Nilai indeks keseragaman pada penelitian ini menunjukkan dalam kategori tinggi. Lokasi Bondan merupakan wilayah yang memiliki nilai keseragaman paling tinggi. Hal ini menunjukkan tidak terdapat jenis yang lebih dominan dari jenis-jenis lainnya, sehingga jenis kepitingnya dapat beranekaragam atau bervariasi. Indeks dominansi pada penelitian ini tidak ditemukan spesies mendominansi, tidak ditemukannya spesies yang mendominansi. Natania et al. (2017) dalam penelitianya di Ekosistem Mangrove Pulau Enggano menjelaskan tidak adanya dominansi dan keseragaman spesies yang tinggi di lokasi penelitian menggambarkan kondisi ekosistem yang tergolong stabil. Kepadatan Uca spp. yang cukup tinggi pada lokasi penelitian menggambarkan habitat mangrove Segara Anakan cocok untuk kehidupan Uca spp.

Nilai indeks keanekaragaman, keseragaman, dan dominansi berkaitan dengan kompetisi ruang dan makanan, habitat, kebiasaan makan dan parameter lingkungan. Krebs (1978) menambahkan, tekanan lingkungan seperti ada atau tidaknya gangguan dari aktivitas manusia dan tingkat sedimentasi akan mempengaruhi perolehan kelimpahan individu masing-masing jenis dan nilai indeks keanekaragaman, keseragaman, dominansi dalam komunitas.

\section{Indeks Kesamaan Komunitas}

Indeks kesamaan komunitas pada penelitian ini masuk dalam kategori sedang dan tinggi. Spesies kepiting yang ditemukan pada lokasi penelitian Segara Anakan memiliki komposisi yang berbeda, sehingga perlu adanya perhitungan nilai indeks kesamaan komunitas untuk mengetahui berapa besar tingkat kesamaan komunitas pada tiap lokasi penelitian. Nilai indeks kesamaan komunitas pada penelitian ini masuk dalam kategori tinggi dan sedang. Nilai indeks kesamaan komunitas per stasiun paling tinggi yaitu pada stasiun Bondan Kalibuntu dan Bondan - Panikel, yaitu mencapai $76,19 \%$ dan $70,59 \%$, yang artinya dalam lokasi tersebut memiliki kesamaan karakteristik vegetasi dan persamaan lingkungan yang cocok untuk jenis kepiting di dalamnya.

Tabel 3. Nilai Indeks Kesamaan Komunitas Kepiting (\%) pada Lokasi Penelitian

\begin{tabular}{lccc}
\hline Lokasi & Panikel & Bondan & Kalibuntu \\
\hline Panikel & - & 70,59 & 50 \\
Bondan & - & - & 76,19 \\
Kalibuntu & - & - & - \\
\hline
\end{tabular}

Tingginya nilai indeks ini disebabkan karena banyak ditemukannya spesies kepiting yang sama pada kedua lokasi tesebut. Lokasi Panikel dan Kalibuntu memiliki indeks kesamaan komunitas yang sedang yaitu $50 \%$, karena ditemukannya sedikit spesies kepiting yang sama antar 2 lokasi ini. Hal ini juga dikarenakan lokasi ini memiliki keanekaragaman yang lebih kecil serta kondisi parameter lingkungan yang sedikit berbeda dikarenakan lokasinya yang relatif dengan aktivitas manusia dan pemukiman.

\section{Pola Sebaran Jenis}

Struktur suatu komunitas alamiah bergantung pada cara biota tersebut menyebar di dalamnya. Pola penyebaran bergantung pada sifat-kimia lingkungan maupun keistimewaan biologis organisme itu sendiri. Hasil yang didapatkan pada penelitian ini menunjukkan jenis yang pola sebarannya mengelompok adalah Uca coarctata, U. crassipes, U. dussumieri, U. tetragonon, dan Metopograpsus messor di hampir semua lokasi penelitian. Penyebaran secara mengelompok atau berumpun, artinya individu-individu selalu dalam kelompok dan sangat jarang terlihat sendiri secara berpisah (Michael, 1994).

Pada lokasi-lokasi penelitian spesies kepiting yang termasuk dalam Famili Ocypodidae dan Grapsidae ini memang ditemukan selalu dalam jumlah yang banyak. Uca spp. hidup mengelompok dengan menempati jumlah lubang yang banyak dan gerakan kepiting ini yang sangat cepat. kepadatan biota tinggi dan individu-individu mengelompok di dalam lokasi penelitian. Kepiting Uca spp. keluar dari lubangnya ketika muka air surut dan 
matahari bersinar cerah. Metopograpsus messor ditemukan memanjat akar-akar mangrove jenis Rhizophora sp. Metopograpsus sp. dan Uca sp. terlihat selalu hadir pada lokasi penelitain dalam jumlah yang banyak.

Spesies kepiting yang pola sebarannya acak antara lain Metaplax elegan dan Uca vocans. Hal ini disebabkan karena jumlah individu yang ditemukan pada masing-masing spesies hanya 2 spesies pada lokasi penelitian. Keberadaan secara acak atau kebetulan artinya individu-individu menyebar dalam beberapa tempat dan mengelompok di tempat lainnya. Pola acak sangat umum terjadi di antara hewan-hewan tingkat rendah karena keberadaan satu individu tidak memberikan pengaruh terhadap biota lain (Michael, 1994).

Pola sebaran biota ini dapat diakibatkan oleh adanya preferensi habitat oleh biota itu sendiri. Pola penyebaran mengelompok dengan tingkat pengelompokkan yang bermacammacam merupakan bentuk penyebaran yang paling umum terjadi, karena individu- individu dalam populasi cenderung membentuk kelompok dalam berbagai ukuran. Penyebaran mengelompok akan meningkatkan persaingan antar individu dalam menanggapi perubahan habitat dan dalam mendapatkan makanan serta ruang gerak. Ulum et al. (2012) dalam penelitiannya di kawasan mangrove kelurahan Tugu Semarang menyatakan pola sebaran ditentukan oleh adanya sifat alam dari dalam individu itu sendiri, yaitu sifat genetika dan kesenangan (preferensi) dalam memilih habitat serta adanya interaksi dari beberapa faktor antara lain : sebaran makanan dalam ruang dan waktu, serta adanya kompetensi dalam pemanfaatan sumber daya habitat yang disebabkan adanya dampak keekstriman dari kondisi lingkungannya.

\section{Parameter Lingkungan}

Parameter lingkungan merupakan faktor penting bagi kawasan mangrove karena mendapatkan pengaruh dari darat dan laut. Parameter lingkungan yang diambil dalam penelitian ini antara lain suhu, salinitas, $\mathrm{pH}$, bahan organik.

Tabel 4. Pola Sebaran Kepiting pada Lokasi Penelitian

\begin{tabular}{|c|c|c|c|c|c|c|}
\hline \multirow{2}{*}{ Spesies } & \multicolumn{2}{|c|}{ Panikel } & \multicolumn{2}{|c|}{ Bondan } & \multicolumn{2}{|c|}{ Kalibuntu } \\
\hline & Id & PS & Id & PS & Id & PS \\
\hline \multicolumn{7}{|l|}{ Ocypodidae } \\
\hline Uca coarctata & 1,01 & C & 1,09 & C & 1,46 & C \\
\hline Uca crassipes & 1,07 & $C$ & 1,50 & C & 1,08 & C \\
\hline Uca dussumieri & 1,08 & C & 1,54 & C & 0,96 & C \\
\hline Uca tetragonon & 1,27 & $C$ & 0,86 & C & 1,07 & C \\
\hline Uca vocans & 0 & $R$ & 0 & $\mathrm{R}$ & - & - \\
\hline \multicolumn{7}{|l|}{ Grapsidae } \\
\hline Episesarma lafondi & - & - & 1,19 & C & 0,75 & C \\
\hline Episesarma versicolor & - & - & 1,80 & C & 0,97 & C \\
\hline Perisesarma bidens & - & - & 0,90 & C & - & - \\
\hline Metaplax elegans & 0 & $R$ & 0,50 & C & - & - \\
\hline Metopograpsus latifrons & - & - & 0,60 & C & 1,20 & C \\
\hline Metopograpsus messor & - & - & 1,61 & C & 0,86 & C \\
\hline \multicolumn{7}{|l|}{ Portunidae } \\
\hline Scylla serrata & - & - & - & & 3,00 & C \\
\hline
\end{tabular}

Ket : $R=$ Random (Acak), $C=$ Clumped (Mengelompok) 
Tabel 5. Pameter Lingkungan Nilai Rata-Rata Parameter Lingkungan (Suhu, Salinitas, pH, Bahan Organik) pada Lokasi Penelitian

\begin{tabular}{|c|c|c|c|c|c|}
\hline \multirow{2}{*}{ Lokasi } & \multicolumn{2}{|c|}{ Suhu ${ }^{\circ} \mathrm{C}$} & \multirow{2}{*}{$\frac{\text { Salinitas\%o }}{\text { Air }}$} & \multirow{2}{*}{$\frac{\mathrm{pH}}{\text { Air }}$} & \multirow{2}{*}{$\frac{\text { Bahan Organik\% }}{\text { Substrat }}$} \\
\hline & Udara & Substrat & & & \\
\hline Panikel & 29 & 28 & 0,5 & 6 & $\begin{array}{c}44,87 \\
(43,29-47,49) \\
19,95\end{array}$ \\
\hline $\begin{array}{l}\text { Bondan } \\
\text { Kali }\end{array}$ & $29-32$ & $28-29$ & 5 & 6 & $\begin{array}{c}(13,86-27,8) \\
22,42\end{array}$ \\
\hline Buntu & $28-29$ & $27-28$ & 20 & 6 & $(21,14-24,83)$ \\
\hline
\end{tabular}

Suhu perairan di lokasi penelitian Segara Anakan Cilacap berkisar 27-32 oC dimana pada lokasi Kali Buntu merupakan lokasi dengan suhu terendah. Nilai pH mencerminkan keseimbangan antara asam dan basa yang akan mempengaruhi pertumbuhan mangrove. Nilai $\mathrm{pH}$ pada lokasi ini sebesar 6 dan tidak ada perbedaan nilai $\mathrm{pH}$ di setiap lokasinya. Salinitas di lokasi penelitian berkisar antara 0,5-20\%. Salinitas terendah berada pada lokasi Panikel sebesar 0,5\% dan tertinggi berada pada lokasi Kali Buntu sebesar $20 \%$. Bahan organik tanah di lokasi penelitian berkisar 19,95 - 44,78\%, bahan organik tanah tertinggi terdapat pada lokasi Panikel dan terendah pada lokasi Bondan dengan $19,95 \%$.

\section{KESIMPULAN}

Kepiting yang ditemukan di lokasi penelitian Segara Anakan Cilacap terdiri dari 3 Famili dan 12 Spesies. Famili Ocypodidae terdiri dari : Uca coarctata, U. crassipes, U. dussumieri, U. tetragonon, dan U. vocans. Famili Grapsidae terdiri dari Metaplex elegans, Episesarma lafondi, E. versicolor, Perisesarma bidens, Metopograpsus latifrons, dan M. messor. Famili Portunidae hanya satu spesies yang ditemukan yaitu Scylla serrata. Kepadatan kepiting tertinggi terdapat pada lokasi Kalibuntu dengan 1,56 ind/m2, kemudian lokasi Bondan dengan 1,43 ind $/ \mathrm{m} 2$, dan lokasi Panikel dengan 1,27 ind/m2. Hasil dari nilai indeks penyebaran Morisita terdapat dua pola sebaran jenis kepiting di lokasi penelitian, yaitu acak dan mengelompok. Secara keseluruhan lokasi penelitian nilai indeks keanekaragaman termasuk dalam kategori sedang. Nilai indeks keseragaman masuk dalam kategori tinggi pada lokasi Bondan dan Kalibuntu, sedangkan lokasi Panikel masuk dalam kategori sedang. Penelitian ini tidak ditemukan spesies yang mendominasi.

\section{DAFTAR PUSTAKA}

Akbar A. A., 2017. Public Participation in the Utilization and Rehabilitation of Coastal Natural Resources (Case Study of Coastal Erosion in West Kalimantan). J. Degraded Mining Lands Management. 4(2):739-747.

Dewi R., 2016. Analisis Perubahan Lahan Kawasan Laguna Segara Anakan Selama Periode Waktu (1978-2016) Menggunakan Satelit Landsat Multitemporal. Omni Akuatika. 12(3):144-14.

[FAO] Management and Agriculture Organization of The United Nations. 1998. FAO Species Identification Guide For Fishery Purpose: The Living Marine Resources of The Western Central Pacific. Volume 2. Rome.

Krebs C. J., 1978. Ecology the Experimental Analysis of Distribution and Abudance. Harper and Row Publisher. New York. $690 \mathrm{pp}$.

C.J. 1989. Experimental Analysis of Distribution and Abudance. Third Edition. Harper Row and Publisher New York. 186-187.

Kusumadewi I., Rudhi P. \& Widianingsih. 2013. Biologi Krustasea di Tracking Mangrove Kawasan Terusan Pulau Kemujan Kepulauan Karimunjawa. J. Mar. Res. 2( 4):94-03.

Michael, P. 1994. Metoda Ekologi untuk Penyelidikan Ladang dan Laboratorium. Universitas Indonesia Press. Jakarta. 
Natania, T., Herliany, N.E. \& Kusuma, A.B. 2017. Struktur Komunitas Kepiting Biola (Uca spp.) di Ekosistem Mangrove Desa Kahyapu Pulau Enggano. J. Enggano 2(1):11-24.

Odum. 1993. Dasar-Dasar Ekologi Umum. Diterjemahkan oleh T. Samingan. Gadjah Mada University Press. Yogyakarta.

Prasetiyo, D.E., Zulfikar, F., Shinta, \& Zulkarnain, I. 2016. Valuasi Ekonomi Mangrove di Pulau Jawa Kepulauan Seribu : Studi Konservasi Berbasis Green Economy. Omni Akuatika. 12(1): 48-54.

Pratiwi R., 2005. Komposisi Keberadaan Krustasea di Mangrove Delta Mahakam Kalimantan Timur. Makara Sains. 13(1):65-76. 2007. Jenis Dan Sebaran Uca Spp. (Crustacea: Decapoda: Ocypodidae) Di daerah Mangrove Delta Mahakam, Kalimantan Timur. Jurnal Perikanan IX. (2):322-328.

Pratiwi R. \& Widyastuti, E. 2013. Pola Sebaran dan Zonasi Krustasea di Hutan Bakau Perairan Teluk Lampung. Zoo Indonesia. 22(1):11-21.

Pratiwi R. \& Rahmat. 2015. Sebaran Kepiting Mangrove (Crustacea: Decapoda) yang terdaftar di Koleksi Rujukan Pusat Penelitian Oseanografi-Lipi 1960-1970. Berita Biologi. 14:2.

Prianto, E. 2007. Peran Kepiting Sebagai Species Kunci (Keystone Spesies) pada Ekosistem Mangrove. Prosiding Forum
Perairan Umum Indonesia IV. Balai Riset Perikanan Perairan Umum. Banyuasin.

Romimohtarto, K., 2001. Biologi Laut. LIPI. Gramedia. Jakarta.

Rosenberg, D. M. \& V. H. Resh. 1993. Freshwater Biomonitoring and Benthic Macroinvertebrates. Chapman and Hall. New York. London

Sasekumar A. 1984. Methods for the Study of Mangrove Fauna. dalam, S.C dan J.G. Snedaker (eds) the Magrove Ecosystem; Reseach Metods, UNESCO, Paris, hlm. 145-161.

Shih Hsi-Te \& H. Suzuki. 2016. Species Diversity of Fiddler Crabs, Genus Uca Leach, $1814 \quad$ (Crustacea: Ocypodidae), from Taiwan and Adjacent islands, with Notes on the Japanese Species. Zootaxa. 4083(1):57-82.

Suryono A.C. 2006. Ekologi Perairan Delta Wulan Demak Jawa Tengah : Distribusi Kepiting (Infra Ordo Brachyura dan Anoumura). Ilmu Kelautan. 11(4):210215.

Ulum M.M., Widianingsih \& Hartati, R. 2012. Komposisi dan Kelimpahan Makrozoobenthos Krustasea di Kawasan Vegetasi Mangrove Kelurahan Tugurejo, Kec. Tugu, Kota Semarang. J. Mar. Res. 1 (2): 243-251.

Wilhm, J. L. 1975. Biological Indicator of Pollution.. In Whitton, B. A (Ed). River Ecology. Blackwell Scientific Public ation. Oxford 37-402. 